\title{
Storage Lifetime of Citrus CV "Siam" from Banyuwangi-East Java-Indonesia
}

\author{
Lailatul Isnainidan and Titik Purbiati \\ Assessment Institue for Agricultural Technology (AIAT), Jl. Raya Karangploso KM.4 Malang, East Java 65101, Indoneisa
}

\begin{abstract}
Banyuwangi is one of the citrus centers in East Java, Indonesia with an estimated 27.7 million metric tons produced with growth in 12.804 hectares. The quality of the citrus will be decreased when the retention of storage is too long because of the physiological changes postharvest. The object of the research is to determine the relevancy of shelf life and quality of the citrus. The research was conducted at Laboratory of Mechanization and postharvest in AIAT East Java and the citrus was obtained in Banyuwangi. This experiment used randomized block design as the method, which the factors are temperature of storage (room temperature $27^{\circ} \mathrm{C}$ and cold temperature $\left.15^{\circ} \mathrm{C}\right)$ and storage time $(0,5,10,15,20$ days) with five replication. The physical parameters in this research are weight, texture, flesh color and skin and the chemical parameters include sugar and acid content. The result of the chemical analysis showed that storage temperature had significant effect on sugar content, but did not have significant effect of acid contents. The storage life time have correlation with sugar and acid contents. Citrus that are storage in refrigerator produce a higher sugar content (14, $20^{\circ}$ brix), but the acid contents are same. The longer that citrus is stored the highest the sugar content. The highest acid content in citrus is storage for 10 days $(0,30 \%)$. The physical analysis showed that storage temperature affects the weight of citrus, but does not affect the texture and color citrus skin. The result showed that citrus which stored in refrigerator is higher than the others. Storage 20 days at room temperature and storage lifetime has no effect on fruit flesh color. The brightness of the surface (L) that is storage 20 days in room temperature has a same value with citrus that is storage in refrigerator.
\end{abstract}

Key words: Citrus sp, storage, physical analysis, chemical analysis.

\section{Introduction}

Fruits and vegetables after harvesting through a living process include physiological, enzymatic, and chemical changes. Physiological changes may affect the characteristic and the quality of products after in photosynthesis, respiration, transpiration and the aging process of product after harvesting. Such processes lead to changes in their contents of various substances in the product, characterized by changes in color, texture, taste and flavor. Storage at low temperatures can inhibit enzyme activity, chemical reactions and inhibit or stop microbial growth. The purpose of storage in low temperature $\left(10^{\circ} \mathrm{C}\right)$ is to prevent the damages without causing undesirable changes such as the decomposition, which means that the condition is

Corresponding author: Lailatul Isnainidan, STP, research field: post harvest technology. not good. The refrigeration treatment can slow down the speed of metabolic reactions where in general every temperature decreases about $8{ }^{\circ} \mathrm{C}$, the reaction rate will decrease to its half [5]. Therefore, storage in low temperatures may extend the lifetime of the tissues in the foodstuffs. This is not only due to the decreased respiratory process, but also because of the microbial growth that causing decay and damage. Chemical contents are degraded to a simple form quickly due to the presence of enzymes. Because of that we need to observe the effect of storage in the chemical changes in a product. The importance of knowing the chemical changes in a product is to provide appropriate postharvest handling, so we are able to maintain the quality in terms of chemical content.

All these quality of fruits and vegetables characteristics can be obtained when harvesting is done at the right level of maturity. Citrus that is harvested when immature will produce a low quality 
especially in the fruit flavor. On the other hand, over time harvesting will cause the fruits losing their best scent and quality, causing the decrease in the next period fruits, increasing sensitivity to decay and the short shelf life [6].

The quality of the fruit has many character, it's like the sweet, sour, bitter flavor, the vitamin A, B, C, and all kinds of nutrients in the fruit. The quality of the fruit is influenced by the length of time in storage, although it also affects the characteristics of the fruit. Fruits usually contain a lot of vitamin $C$ which has great benefits. Many fruits have a sweet taste that has the ability to replace the usual sugar. However, not all fruits will produce a sweet taste, there are also fruits that have a sour taste. The fruit characteristics will change during the process, both storage before harvest and post-harvest time [1]. It is important to know the changes to determine a good treatment in storage, and maintain the quality of the fruit. The purpose of this study is to determine the storage lifetime of citrus and the fruit quality.

\section{Methodology}

The material is citrus of Siam Pontianak (Simpon) obtained from farmers in the Village Temujerodistrict Bangorejo Kab, Banyuwangi. The fruits are selected and cleaned, the weight of the fruits range about 125-125 g/buah. After that, the fruits were stored in room temperature and cold temperature (refrigerator). This research consists of 2 factors: factor 1: Storage Temperature (room $27{ }^{\circ} \mathrm{C}$ and cold temperature $15{ }^{\circ} \mathrm{C}$ ) and factor 2: Storage Time (0, 5, 10, 15, 20 days) after harvest. Each treatment was repeated 5 times and each replication using 5 random oranges taken randomly.

The parameters observed in this study were physically encompassing fruit weight, fruit texture, meat and fruit skin color (L, a*, b*) and chemically include sugar content ( ${ }^{\circ}$ brix) and acid levels (\%) [9]. This research used Factorial Randomized Block Design (RAK) with 2 treatments and 5 replications. The results are analyzed by variance (ANOVA) and if there is a real difference and then is continued with Duncun test at $5 \%$ significant level.

\section{Result and Discussion}

The results of the research showed that storage temperature had an effect on sugar content of citrus fruit. Siam Citrus that stored at refrigerator temperature $\left(15{ }^{\circ} \mathrm{C}\right)$ has higher sugar content (14.20) than at room temperature (13.03). Oranges that stored for 20 days contain sugar content reaching (28.90) while oranges that storage for 10-15 days decreased sugar content (9.50) (Table 1). This decrease describes the occurrence of damage (denaturation) of enzymes. According to [6] the decrease of respiration rate at high temperatures is a sign that: (A) $\mathrm{O}_{2}$ does not diffuse fast enough to maintain the rate of respiration present; (B) $\mathrm{CO}_{2}$ accumulated in cells to levels that can inhibit metabolism; (C) The oxidized feedstock supply is insufficient to maintain a high rate of respiration.

Table 1 Storage lifetime siam citrus according to sugar content and acid content.

\begin{tabular}{lll}
\hline \multirow{2}{*}{ Treatment } & \multicolumn{1}{c}{ Chemical analysis } \\
\cline { 2 - 3 } & Sugar content $\left({ }^{\mathrm{o}}\right.$ brix $)$ & Acid content (\%) \\
\hline Storage temperature $\left({ }^{\circ} \mathrm{C}\right)$ & $13.03^{\mathrm{b}}$ & $0.30^{\mathrm{a}}$ \\
Room temperature $\left(27^{\circ} \mathrm{C}\right)$ & $14.20^{\mathrm{a}}$ & $0.24^{\mathrm{a}}$ \\
Refrigeration temperature $\left(15^{\circ} \mathrm{C}\right)$ & & \\
Storage duration (days) & $10.10^{\mathrm{b}}$ & $0.27^{\mathrm{ab}}$ \\
0 & $10.09^{\mathrm{b}}$ & $0.25^{\mathrm{b}}$ \\
5 & $9.50^{\mathrm{b}}$ & $0.30^{\mathrm{a}}$ \\
10 & $9.50^{\mathrm{b}}$ & $0.28^{\mathrm{ab}}$ \\
15 & $28.90^{\mathrm{a}}$ & $0.25^{\mathrm{b}}$ \\
\hline
\end{tabular}

Ket: The numbers in the same column with the same letters indicate there is no significant difference according to BNT 5\%. 
The rate of respiration is influenced by internal and external factors. Internal factors are factors derived from the ingredients (fruits and vegetables), including the level of organ development, chemical composition of tissue, product size, natural coating and tissue type. External factors are factors that originate from the surroundings of the material including temperature, ethylene, the availability of oxygen, carbon dioxide and cut on the material. Respiratory rate is faster if the storage temperature is high, the age of young harvest, the larger fruit size, the presence of fruit cut and the high initial sugar content of the product [11]. According to [11], the increase in total sugar occurs due to the accumulation of sugar as a result of starch degradation, because during the maturation occurs the hydrolysis of polysaccharides into simple sugars, whereas the decrease in total sugar occurs because some sugar is used for the respiration process, because the sugar is used as the substrate respiration to produce energy.

In contrast to the conjoined citrus siam acid content, at different storage temperatures did not affect the acid level but the citrus acid content significantly affected the storage period. Levels of citrus acid during 10 days storage had the highest acid content but decreased in the 20 days storage (Table 1).

Differences in harvest age can affect vitamin C content, it says by [6] that the content of ascorbic acid differs in maturity level and increases according to maturity. Citrus fruits stored at room temperature provide higher levels of TPT, indicating that low storage temperatures will inhibit the maturation process. It is also reported by Antarlina and Noor [2] that handling with cold storage for perishable fruits can reduce the aging process due to the process of maturation, softening, color and texture changes.

Fruit weight significantly affect the temperature and storage time. The weight of the fruit that stored at refrigerator temperature $\left(15{ }^{\circ} \mathrm{C}\right)$ is greater (156.39) than the weight of at room temperature (134.84) (Table 2). The decrease of fruit weight occurred because the length of storage time is 20 days. The longer fruit stored at room temperature then fruit weight decreases (Table 2).

During the fruit storage process there will be shrinkage of weight caused by the loss of water in the process of transpiration and respiration. This causes the weight loss to increase the length of storage. There is a considerable difference in weight loss, about $20 \%$ between the shrinkage of fruit weight stored at room temperature and the refrigerator temperature where the fruits stored at room temperature are more rapidly losing weight than the fruits stored at refrigerator temperature.

There is a tendency at room temperature that young harvested fruits experience shrinkage greater weight than fruits whose age of harvest is older. But in cold temperatures seen the opposite phenomenon, the fruit with the age of younger quotes tend to be smaller shrinkage weight than the fruit with older picking age [10]. Fruit with high weight loss will cause the fruit to

Table 2 Physical analysis of citrus siam storage lifetime.

\begin{tabular}{llll}
\hline Treatment & \multicolumn{2}{c}{ Physical analysis } \\
\cline { 2 - 4 } & Fruit weight (gram) & Texture $(\mathrm{g} / \mathrm{s})$ & Skin color $\left(\mathrm{a}^{*}\right)$ \\
\hline Storage temperature $\left({ }^{\circ} \mathrm{C}\right)$ & $134.84^{\mathrm{b}}$ & $0.48^{\mathrm{a}}$ & $3.37^{\mathrm{a}}$ \\
Room temperature $\left(27^{\circ} \mathrm{C}\right)$ & $156.39^{\mathrm{a}}$ & $0.57^{\mathrm{a}}$ & $0.25^{\mathrm{b}}$ \\
Refrigeration temperature $\left(15^{\circ} \mathrm{C}\right)$ & & & $-5.56^{\mathrm{c}}$ \\
Storage duration (days) & $153.63^{\mathrm{a}}$ & $0.55^{\mathrm{ab}}$ & $3.03^{\mathrm{b}}$ \\
0 & $150.37^{\mathrm{a}}$ & $0.34^{\mathrm{c}}$ & $14.33^{\mathrm{a}}$ \\
5 & $143.44^{\mathrm{a}}$ & $0.54^{\mathrm{ab}}$ & $-2.19^{\mathrm{bc}}$ \\
10 & $142.55^{\mathrm{a}}$ & $0.52^{\mathrm{b}}$ & $0.56^{\mathrm{bc}}$ \\
\hline
\end{tabular}

Ket: The numbers in the same column with the same letters indicate there is no significant difference according to BNT $5 \%$. 
lose its freshness, the fruit becomes wrinkled with wrinkled skin so that the appearance of the fruit becomes unattractive and no longer worth marketed. Very large weight loss role determines the shelf life of the fruit.

Storage of oranges at refrigerator temperatures and longer storage results a harder texture fruit than storage at room temperature. The decrease in the hardness of the citrus fruit is caused during the storage of the fruit undergoing maturity changes so that the fruit hardness level changes. This change is caused by degeneration of compounds making up the cell wall of fruit. Chemically, cell walls are composed of complex compounds consisting of cellulose, hemi cellulose, pectin and lignin substances. The occurrence of this degeneration is due to the presence of several bacteria that hydrolyze cellulose into simpler compounds. Fruit softness due to insoluble pectin (protopectin) decreases in number and pectin becomes easily soluble [10].

The hardness of citrus fruits at refrigerator temperature $\left(15^{\circ} \mathrm{C}\right)$ is slightly higher than room temperature, it can be caused because cold storage can inhibit metabolism process, ripening, softening and aging, while texture of citrus fruits at room temperature quickly becomes soft, because the process of evaporation is higher caused the decrease of hardness and the change of cell wall changes caused by the degradation of cell wall compounds. This shows that low temperatures can maintain the fruit texture until the end of storage [8].
Color is usually used by consumers to indicate the quality of fruit to be consumed, so the color becomes the appeal of consumers. The most suitable and easy to use of indicate orange maturity is the color change of the fruit skin. The color of citrus at the beginning of storage is yellowish green. In the treatment of storage temperature has a significant effect on skin color a* (greenish). Citrus skin color stored at room temperature is more yellowish $\left(a^{*}+3.37\right)$ while the skin at refrigeration temperature storage is more greenish color $\left(\mathrm{a}^{*}+0.25\right)$.

Based on Table 3 there is an interaction between temperature and storage time to the citrus skin color lightness. Citrus skin color at room temperature during storage in 15-20 days $(\mathrm{L}+10.25)$ is brighter than storage in 0-10 days $(L+7.84)$. Based on visual appearance of the color of citrus fruits stored at room temperature showed towards yellow up to storage in 20 days whether citrus fruits stored at refrigerator temperature $\left(15{ }^{\circ} \mathrm{C}\right)$ look still that can be maintained the freshness of citrus fruit color up to 20 days storage time $(\mathrm{L}+8.60)$. This is because low temperatures causing the chlorophyll degradation process was slower during storage time. According to [8] who suggests that the temperature of storage temperature is the main factor that affects the occurrence of chlorophyll degradation. Chemical and physiological changes of citrus fruit are closely related to the change of citrus color. The more mature citrus is, the more yellow its skin is. Citrus at refrigerator storage for 10 days $(L+4.11)$ and room temperature

Table 3 The interaction between temperature and storage time citrus "siam” according to fruit skin lightness.

\begin{tabular}{ll}
\hline Treatment & Fruit skin L* (lightness) \\
\hline Storage 0 day in room temperature & $8.12^{\mathrm{ab}}$ \\
Storage 5 days in room temperature & $7.48^{\mathrm{ab}}$ \\
Storage 10 days in room temperature & $8.72^{\mathrm{ab}}$ \\
Storage 15 days in room temperature & $10.25^{\mathrm{a}}$ \\
Storage 20 day in room temperature & $10.12^{\mathrm{a}}$ \\
Storage 0 day in refrigeration temperature & $8.70^{\mathrm{ab}}$ \\
Storage 5 days in refrigeration temperature & $8.10^{\mathrm{ab}}$ \\
Storage 10 days in refrigeration temperature & $4.11^{\mathrm{b}}$ \\
Storage 15 days in refrigeration temperature & $8.18^{\mathrm{ab}}$ \\
Storage 20 days in refrigeration temperature & $8.60^{\mathrm{ab}}$ \\
\hline
\end{tabular}

Ket: The numbers in the same column with the same letters indicate there is no significant difference according to BNT 5\%. 
Table 4 Storage lifetime citrus cv "siam" according to fruit flesh.

\begin{tabular}{|c|c|c|c|}
\hline \multirow{2}{*}{ Treatment } & \multicolumn{3}{|c|}{ Fruit flesh color } \\
\hline & Lightness $\left(\mathrm{L}^{*}\right)$ & Red/green (a*) & Yellow/blue (b*) \\
\hline \multicolumn{4}{|l|}{$\overline{\text { Storage temperature }\left({ }^{\circ} \mathrm{C}\right)}$} \\
\hline Room temperature $\left(27^{\circ} \mathrm{C}\right)$ & $25.60^{\mathrm{tn}}$ & $12.32^{\mathrm{tn}}$ & $24.48^{\mathrm{tn}}$ \\
\hline Refrigeration temperature $\left(15^{\circ} \mathrm{C}\right)$ & $27.75^{\mathrm{tn}}$ & $10.44^{\operatorname{tn}}$ & $28.84^{\mathrm{tn}}$ \\
\hline \multicolumn{4}{|l|}{ Storage time (days) } \\
\hline 0 & $3.3^{\mathrm{tn}}$ & $12.21^{\mathrm{tn}}$ & $27.92^{\mathrm{tn}}$ \\
\hline 5 & $27.0^{\mathrm{tn}}$ & $11.18^{\mathrm{tn}}$ & $15.01^{\mathrm{tn}}$ \\
\hline 10 & $22.41^{\text {tn }}$ & $12.2^{\text {th }}$ & $35.22^{\text {tn }}$ \\
\hline 15 & $29.16^{\mathrm{tn}}$ & $5.97^{\mathrm{tn}}$ & $21.73^{\operatorname{tn}}$ \\
\hline 20 & $24.49^{\text {tn }}$ & $15.34^{\mathrm{tn}}$ & $33.42^{\text {tn }}$ \\
\hline
\end{tabular}

Ket: The numbers in the same column with the same letters indicate there is no significant difference according to BNT $5 \%$.

for 5 days storage $(\mathrm{L}+7.48)$ decreased brightness. This indicates degradation in the Lightness of citrus fruit color, possibly due to the effect of the aging process (senescence) that occurs in citrus fruits.

Citrus pulp color measurement is done by color reader to obtain the value of $L^{*}, a^{*}$ and $b^{*}$. Based on Table 4 , it is obtained that temperature and storage time has no significant effect on the color of citrus fruit flesh. Almost all the fruit flesh color has the same color which is orange.

\section{Conclusions}

Storage temperature and storage time have significant effect on citrus fruit content but storage temperature has no significant effect on acid level but storage time has significant effect on citrus acid level.

Temperature and storage time of siam citrus have a significant effect on fruit weight and skin color $\mathrm{a}^{*}$. The storage temperature has no significant effect on the texture of the fruit but the storage time has an effect on the fruit texture.

There is interaction between temperature and storage time to the citrus skin color lightness $\left(\mathrm{L}^{*}\right)$, at room temperature during storage in 15-20 days having the most lightness level.

Temperature and storage time have no significantly affect the color of citrus fruit flesh $\mathrm{L}^{*}, \mathrm{a}^{*}, \mathrm{~b}^{*}$.

\section{References}

[1] Adar, D., and M. Ban. 2003. "Consumer Appetite for JKS in Several Cities in Indonesia." Proceedings of the National Seminar on Communications of Research
Results and Assessments Development of Tangerine SoE.SoE, 210-7.

[2] Antarlina, S. S., and Noor, I. 2006. "Post-Harvest Handling and Processing of Siamese Citrus Fruits in Orange Siam Monographs in Tidal Lands Management and Development.” Indonesian Center for Research and Development of Agricultural Land Resources. Balittra. Banjarbaru.

[3] Buckle, K. A., Edward, R. A., Fleet, G. H., and Wootton. M. 1987. Food Science. Translated by Hari Purnomo and Adiono. Jakarta: UI-Press.

[4] Budiastra, W., and Purwadaria, H. K., 1993. "Postharvest Handling of Vegetables and Fruits in the House of Packaging.” Paper Postharvest Training Vegetables and Fruits. Bogor, 10-5.

[5] DeMan, John. M. 1997. Food Chemistry. Translated by Kosasih Padmawinata. Bandung: ITB Publisher.

[6] Pantastico, Er. B., Subramanyan, H., Bhatti, M. B., Ali, N., and Akamine, E. K. 1993. "Post-Harvest Physiology, Handling and Utilization of Tropical Fruits and Vegetables Sub Tropics.” Instructions for Harvesting Results. Edited by Pantastico, Er. B. Yogyakarta: UGM Press, 91-119.

[7] Santoso, B. B., and Purwoko, B. S. 1995. "Physiology and Postharvest of Horticultural Plants.” Indonesia Australia Eastern Universities Project.

[8] Satuhu, S. 1994. Handling and Processing of Fruit. Jakarta: PT Penebar Swadaya.

[9] Sudarmadji, S., and Bambang Haryono, Suhardi. 1996. Analysis of Food Ingredients and Agriculture. Yogyakarta: Publisher of Liberty.

[10] Susanto, S. 2004. "Changes in the Quality of Fremint Citrus Fruits (Citrus Reticulata) Harvested from Different Height Levels of Land during Storage.” Proceedings of National Siuk Siam Seminar, Surabaya Research and Development Center Horticulture, 415-23.

[11] Winarno, F. G. 1997. Food Chemistry and Nutrition. Jakarta: PT Gramedia Pustaka Utama. 